DOI: 10.22630/EIOGZ.2014.108.39

Zeszyty Naukowe Szkoły Głównej Gospodarstwa Wiejskiego

Ekonomika i Organizacja Gospodarki Żywnościowej nr 108, 2014: 55-68

Katarzyna Zajda, Elżbieta Psyk-Piotrowska

Katedra Socjologii Wsi i Miasta

Uniwersytet Łódzki

\title{
Oddziaływanie programu LEADER na kapitał społeczny mieszkanek wsi
}

\section{Wstęp}

Aktywność społeczna Polaków (zarówno formalna, jak i nieformalna) od lat wzbudza zainteresowanie badaczy. Do zmiennych, które ją różnicują, należą wykształcenie, wiek, udział w praktykach religijnych, status materialny, reprezentowana kategoria zawodowa, płeć oraz miejsce zamieszkania [Boguszewski 2012, s. 12]. W świetle rozważań prezentowanych w niniejszym artykule dwie ostatnie wydają się szczególnie interesujące.

Do organizacji pozarządowych częściej należą mężczyźni niż kobiety, choć na te statystyki wpływa ich członkostwo w stowarzyszeniach sportowych stanowiących jedną trzecią wszystkich polskich organizacji tego typu. Kobiety częściej zasilają natomiast stały personel organizacji (stanowią 55\% jego regularnych pracowników), częściej pełnią w nich rolę wolontariuszek oraz działają społecznie poza strukturami sformalizowanymi. Angażują się głównie w działania na rzecz edukacji, ochrony zdrowia i pomocy społecznej [Przewłocka i in. 2013, 90-91].

Mieszkańcy wsi cechują się niskim poziomem aktywności w organizacjach obywatelskich, ale to oni, biorąc pod uwagę aktywność niesformalizowana, wypadają lepiej niż mieszkańcy innych zbiorowości terytorialnych (poza mieszkańcami największych miast) [Boguszewski 2012, s. 9, 12]. Specyfika ich aktywności wiąże się z cechami wiejskiego trzeciego sektora (nie bez przyczyny w literaturze przedmiotu opisywanego jako ,inny trzeci sektor”). Organizacji pozarządowych na wsi jest bowiem mniej, są uboższe niż organizacje funkcjonujące na obszarze miast, częściej zmagają się z deficytami kadrowymi, rzadziej pozyskują zewnętrzne środki na działalność (zwłaszcza z Unii Europejskiej) [zob. Herbst 2008, Kamiński 2008]. 
Połączenie tych dwóch kategorii pozwala na uchwycenie charakterystycznych cech społecznej aktywności kobiet wiejskich. Większość z nich (83\%) nie należy do żadnej organizacji pozarządowej. Te, które deklarują przynależność do jakiejś organizacji wymieniają przede wszystkim komitety rodzicielskie, rady rodziców, koła gospodyń wiejskich oraz ruchy religijne, kościelne, wspólnoty parafialne. Walczak-Duraj (na postawie reprezentatywnych badań przeprowadzonych w 2008 roku na próbie dorosłych mieszkanek wsi) podkreśla, iż ich aktywność społeczna przebiega głównie poza ramami formalnych organizacji. Wskazuje na to chociażby fakt, iż 3/4 kobiet zamieszkujących wieś w przeszłości lub aktualnie dobrowolnie i nieodpłatnie wykonywało prace na rzecz swoich sąsiadów, ponad połowa pracowała na rzecz innych mieszkańców wsi, a nieco więcej niż co czwarta również na rzecz mieszkańców swojej gminy. Niemal co trzecia brała udział w zebraniach wiejskich organizowanych przez sołtysów, a co czwarta składała (osobiście lub w porozumieniu z innymi członkami społeczności lokalnej) postulaty, prośby lub żądania do władz lokalnych [Walczak-Duraj 2008, s. 136, 140]. W systemie wartości kobiet wiejskich udział w życiu społeczno-politycznym znalazł się na trzecim od końca miejscu (przed życiem pełnym przygód, sukcesem i sława). Aprobowało go jedynie 7\% ich ogółu (w stosunku do 9\% mężczyzn) [Walczak-Duraj 2008, s. 142]. Organizacjami, do których kobiety wiejskie potencjalnie chciałyby zgłosić akces w przyszłości były organizacje charytatywne, głównie działające na rzecz potrzebujących dzieci, a w dalszej kolejności osób starszych, ubogich, ofiar klęsk żywiołowych. A zatem w profilu aktywności społecznej kobiet wiejskich (aktualnej i potencjalnej) ujawniają się cechy ich socjalizacji, definicje odgrywanych na co dzień ról społecznych, wśród których dominują nadal te tradycyjne (matki, żony, opiekunki) [por. Michalska 2013]. Mimo niskiego poziomu (cechującej je) sformalizowanej partycypacji społecznej mieszkanki wsi stanowią duży potencjał społeczeństwa obywatelskiego na wsi.

Wdrożenie podejścia LEADER zaowocowało powstaniem nowych i specyficznych organizacji pozarządowych, struktur hybrydowych tworzonych przez reprezentantów trzech sektorów (publicznego, gospodarczego i społecznego), gotowych (przynajmniej w założeniu) współdziałać w imię zrównoważonego i wielofunkcyjnego rozwoju obszaru partnerstwa (tworzonego najczęściej przez kilka, kilkanaście gmin). W tych organizacjach (określanych mianem lokalnych grup działania, dalej LGD) upatruje się szansy na pobudzenie sformalizowanej aktywności społecznej mieszkańców wsi, budowę ich kapitału społecznego. W Programie Rozwoju Obszarów Wiejskich na lata 2007-2013 czytamy: „Leader jest podejściem wielosektorowym, przekrojowym i partnerskim, realizowanym lokalnie na określonym obszarze, umożliwiającym osiągnięcie celów osi trzeciej. 
Celem osi czwartej jest przede wszystkim budowanie kapitału społecznego poprzez aktywizację mieszkańców oraz przyczynianie się do powstawania nowych miejsc pracy na obszarach wiejskich, a także polepszenie zarządzania lokalnymi zasobami i ich waloryzacja, wskutek pośredniego włączenia lokalnych grup działania w system zarządzania danym obszarem" [PROW 2007-2013, s. 294].

Wzmocnienie kapitału społecznego mieszkańców wsi ma być konsekwencją ich uczestnictwa w lokalnych grupach działania, ale też aktywizującej roli tych organizacji w stosunku do członków społeczności lokalnej. Realizacja różnych projektów, inicjatyw ma nie tylko służyć zaspokajaniu potrzeb lokalnych, ale również wzmocnieniu postaw partycypacji społecznej. Choć, jak zauważa Bukraba-Rylska „LEADER, wdrażany od początku członkostwa Polski w Unii Europejskiej, "przyzwyczaił« komentatorów do pozytywnych ocen” [2011, s. 34]. Coraz częściej wskazuje się na różnego rodzaju mankamenty lokalnych grup działania, niepokojące zjawiska i procesy, które to oddziaływanie mogą utrudniać. Literatura przedmiotu dostarcza wielu interesujących danych na ten temat. Badacze do grupy czynników ograniczających aktywizującą rolę LGD zaliczają m.in. proces ich petryfikacji, wysoki poziom profesjonalizacji i ekonomizacji [zob. Zajda 2011, Psyk-Piotrowska i in. 2013], jak również zdominowanie tych organizacji przez władze samorządowe niechętne nowym liderom politycznym [zob. Knieć 2007, Halamska i in. 2010, Knieć 2010, Halamska 2011, Furmankiewicz 2013]. Pytaniem nadal pozostaje, czy kapitałotwórcza rola lokalnych grup działania $\mathrm{w}$ jednakowym stopniu dotyczy kobiet i mężczyzn zrzeszonych w ich strukturach.

\section{Cele i metody}

Przedmiotem rozważań $\mathrm{w}$ niniejszym artykule jest oddziaływanie podejścia LEADER na kapitał społeczny mieszkanek wsi zaangażowanych w prace lokalnych grup działania, a jego celem scharakteryzowanie cech tego kapitału. W opracowaniu przyjęto definicję kapitału społecznego autorstwa Putnama, zgodnie z którą „odnosi się [on, K.Z.] do takich cech organizacji społeczeństwa, jak zaufanie, normy i powiązania, które mogą zwiększyć sprawność społeczeństwa, ułatwiając skoordynowane działania" [1995, s. 258]. Zaproponowane przez autora ujęcie wielokomponentowe pozwala na analizę sieci społecznych, w których uczestniczą mieszkanki wsi w nawiązaniu do cechującego ich poziomu zaufania społecznego oraz aprobowanych norm i wartości. Tak więc badane będą trzy komponenty tego kapitału, tj. zaufania, norm i wartości oraz sieci. W ramach każdego z nich wyszczególniono kilka zmiennych. Ze względu na 
fakt, iż określenie cech kapitału społecznego kobiet zaangażowanych w prace lokalnych grup działania wymaga jakiegoś odniesienia, ich wartości prezentowane będą dla kobiet i mężczyzn zrzeszonych w tych organizacjach.

W ramach komponentu zaufania analizowane będą zaufanie badanych do: 1) osób znanych (rodziny, sąsiadów, współpracowników spoza LGD oraz współpracowników z LGD), 2) cechujące ich zaufanie społeczne (zaufanie do osób obcych spotykanych w różnych sytuacjach życiowych) oraz 3) zaufanie do instytucji i organizacji lokalnych (władz lokalnych, organizacji pozarządowych, lokalnych przedsiębiorców).

W ramach komponentu norm, wartości analizie podlegał będzie: 1) patriotyzm lokalny badanych (więź z gminą zamieszkania, uczestnictwo w ostatnich wyborach samorządowych, gotowość ponoszenia wydatków finansowych na rzecz promowania lokalnej kultury), 2) podzielane przez nich normy i wartości związane z podejściem LEADER, tj. przekonanie o tym, iż wszyscy członkowie tej organizacji powinni współpracować niezależnie od tego czy reprezentują sektor społeczny, publiczny czy gospodarczy oraz przeświadczenie o konieczności współpracy na rzecz partnerstwa, 3) społecznikostwo badanych - chęć kontynuacji działania w LGD, gotowość do niesienia pomocy innym ludziom, właściwy im poziom poczucia podmiotowości (rozumiany jako przekonanie o posiadaniu kontroli nad własnym życiem).

W ramach komponentu sieci zbadane zostanie: 1) zaangażowanie członków LGD w sieci współpracy na rzecz partnerstwa lub gminy, 2) ich uczestnictwo w pracach tych organizacji, 3) poczucie wpływu na funkcjonowanie partnerstwa (partycypacja w procesach decyzyjnych grupy oraz przekonanie o wpływie działań LGD na rozwój partnerstwa).

W opracowaniu wykorzystano część materiału empirycznego pozyskanego w związku z realizacją projektu badawczego: „Struktura i uwarunkowania kapitału społecznego lokalnych grup działania" . W badaniach surveyowych wykorzystano technikę ankiety rozdawanej. Wypełniło ją 238 kobiet (co stanowiło $42,1 \%$ próby) i 327 mężczyzn (odpowiednio $57,9 \%$ próby) należących do 59 LGD usytuowanych na obszarze 6 województw (o najmniejszej i największej liczbie tych organizacji funkcjonujących na ich obszarze), tj. lubuskiego, opolskiego, zachodniopomorskiego oraz podkarpackiego, małopolskiego i wielkopolskiego ${ }^{2}$.

\footnotetext{
${ }^{1}$ Grant Narodowego Centrum Nauki, umowa nr 6996/B/H03/2011/40) w okresie 2011-2013. Więcej o metodologii badania w E. Psyk-Piotrowska, K. Zajda, A. Kretek-Kamińska, D. Walczak-Duraj, 2013: Struktura i uwarunkowania kapitału społecznego lokalnych grup działania, Wydawnictwo UŁ, Łódź.

2 Obiektem badania były lokalne grupy działania, które wdrażały Pilotażowy Program LEADER+.
} 


\section{Wyniki badań i dyskusja}

Kobiety zrzeszone w lokalnych grupach działania można podzielić na dwie kategorie: do pierwszej należą kobiety uczestniczące w pracach zarządu, radzie lub komisji rewizyjnej (nieco ponad połowa respondentek), do drugiej szeregowe członkinie, niezaangażowane w prace struktur kolegialnych. Największy odsetek badanych należał do organu decyzyjnego - rady (najczęściej liczącego kilkanaście osób), najmniejszy do organu kontroli wewnętrznej - komisji rewizyjnej (najczęściej liczącej kilka osób). Ich aktywność w tych organach była mniejsza od aktywności mężczyzn (tab. 1).

Liczebna przewaga mężczyzn we władzach lokalnych grup działania mogła wiązać się z samorzutnym doborem próby. Respondentami byli najaktywniejsi członkowie, tj. ci, którzy uczestniczyli w pracach zarządów, rad, komisji rewizyjnych oraz brali udział w walnych zebraniach członków lokalnych grup działania.

Więcej niż połowa badanych kobiet $(56,4 \%)$ ukończyła studia wyższe (co stanowi mniejszy odsetek niż w kategorii mężczyzn - 61,7\%). Wykształcenie podstawowe i zasadnicze zawodowe posiadało $9,7 \%$ ich ogółu (w stosunku do 9,8\% mężczyzn). Około $77 \%$ respondentek i $86 \%$ respondentów było aktywnych zawodowo, większość wykonywała prace umysłowe jako pracownicy biurowi, handlu i usług, byli specjalistami lub należeli do kadr kierowniczych. Te cechy badanych wpisują się w wizerunek Polaków aktywnych w sektorze organizacji pozarządowych. Jak wynika $z$ analiz CBOS, społecznie aktywne są częściej osoby bardzo dobrze wykształcone, pracujące zawodowo, zwłaszcza w charakterze kadry kierowniczej, specjalistów wyższego szczebla. Do organizacji obywatelskich często wstępują również pracownicy średniego szczebla [Boguszewski 2012, s. 4, 5, Hipsz 2012, s. 2, 13, Kinowska 2013, s. 3].

Najwięcej respondentek (30,5\%) było w wieku 45-54 lata (analogicznie $29,6 \%$ mężczyzn). Nieco więcej niż co piąta badana (21,4\%) liczyła 55-64 lata (odsetek mężczyzn w tym wieku był wyższy i wynosił $28,7 \%$ ). Około $24 \%$ ko-

\section{Tabela 1}

Uczestnictwo respondentów w organach lokalnych grup działania

\begin{tabular}{|c|c|c|c|}
\hline \multirow{2}{*}{ Płeć } & \multicolumn{3}{|c|}{ Odsetek respondentów pełniących funkcję w organach lokalnych grup dzia- } \\
& tania, $N=555[\%]$ & członek komisji rewizyjnej \\
\cline { 2 - 4 } & członek zarządu & członek rady & 4,2 \\
\hline Kobieta & 22 & 26,3 & 7,8 \\
\hline Mężczyzna & 23,2 & 35,4 & czlo \\
\hline
\end{tabular}

Źródło: Opracowanie własne. 
biet (i 20\% mężczyzn) znajdowało się w wieku 35-44 lata. Wśród respondentów (poza 4 kobietami i 2 mężczyznami) nie znajdowały się osoby pełnoletnie poniżej 24 roku życia. Niewielki był również odsetek osób w wieku $65+(5,5 \%$ kobiet i 8,5\% mężczyzn). Zatem nieco więcej badanych kobiet niż mężczyzn mieści się w ,młodszych” grupach wieku (35-54 lat). Generalnie struktura wieku badanych odróżnia tę zbiorowość od ogólnopolskiej próby osób zaangażowanych w prace organizacji pozarządowych. Wśród niej dominują bowiem osoby w wieku 35-44 lata oraz osoby młode w wieku od 18 do 24 lat [Boguszewski 2012. s. 5]. W tak wysoce sprofesjonalizowanych organizacjach jak lokalne grupy działania najwyraźniej mało jest miejsca na aktywność (zwłaszcza w charakterze tzw. osób funkcyjnych) dla młodzieży wiejskiej [Psyk-Piotrowska i in. 2013, s. 52].

Badane kobiety reprezentowały głównie sektor społeczny (przynależność do niego zadeklarowało 62,5\% ich ogółu). Do sektora publicznego i gospodarczego należało odpowiednio 23,5 oraz $14 \%$ ich ogółu. Wyniki badań nie upoważniają jednak do wniosku, iż w lokalnych grupach działania najaktywniejsze są osoby rekrutujące się z grona lokalnych organizacji pozarządowych (mniej czy bardziej sformalizowanych). Należy bowiem mieć na uwadze zjawisko municypalizacji w obrębie LGD, którego jedną z form jest ukrywanie się pod szyldem NGO faktycznych reprezentantów sektora publicznego [Furmankiewicz i Królikowska 2010, s. 86, Knieć 2010, s. 5, Halamska i in. 2010, s. 112].

$Z$ analizy cech wchodzących do komponentów kapitału społecznego wynika, że niższe wartości określają poziom zaufania kobiet niż mężczyzn. Stosunkowo wysoki poziom zaufania do osób znanych jest wspólny dla wszystkich respondentów (podobnie jak dla zdecydowanej większości Polaków). Największym poziomem zaufania badanych do instytucji i organizacji lokalnych cieszyły się organizacje pozarządowe (51,7\% kobiet w stosunku do $56 \%$ mężczyzn), nieco mniejszy odsetek badanych zadeklarował ufność w stosunku do władz lokalnych (42,6\% kobiet oraz 46,5\% mężczyzn). Najmniejszym zaufaniem obdarzani byli lokalni przedsiębiorcy (ufało im 20,1\% kobiet i 30,8\% mężczyzn). Zaufanie do osób obcych spotykanych w różnych sytuacjach życiowych wyrażało $17,6 \%$ kobiet oraz 21,2\% mężczyzn zrzeszonych w LGD. Bardziej zróżnicowane były deklaracje przedstawicieli obu płci dotyczące zaufania do współpracowników z lokalnych grup działania. Reprezentantom sektora publicznego ufało $60,4 \%$ kobiet oraz $68,9 \%$ mężczyzn, sektora gospodarczego odpowiednio 50,2\% kobiet oraz $60,6 \%$ mężczyzn, a zaufanie do przedstawicieli sektora społecznego deklarowało $68,4 \%$ kobiet oraz $72,8 \%$ mężczyzn. Stworzony indeks zaufania ${ }^{3}$, który

\footnotetext{
${ }^{3}$ Tworząc go, stworzono zmienne syntetyczne (zaufanie do osób znanych, zaufanie społeczne oraz zaufanie do instytucji i organizacji), z których każda przybrała wartości od 0 (brak zaufania) do 2 (duże zaufanie). 1 oznaczała umiarkowany poziom zaufania).
} 
przybrał wartość od 0 do $6^{4}$, zróżnicował badane podzbiorowości według płci. Kobiety zrzeszone w lokalnych grupach działania rzadziej niż mężczyźni osiągały wartości najwyższe (odsetek tych, którym można przypisać 5 i 6 wynosił 29,4\%, analogiczny odsetek dla mężczyzn to $35,2 \%$ ) - tabela 2 .

Analizując cechy składające się na komponent norm i wartości stwierdzono, że kobiety rzadziej niż mężczyźni (odpowiednio 49,1 oraz 59,6\%) wykazywały zadowolenie z przystapienia do LGD. Nie zauważono żadnej różnicy między nimi w zakresie planów dotyczących dalszego uczestnictwa $\mathrm{w}$ tych organizacjach ( $w$ obu przypadkach chęć dalszego członkostwa w nich zadeklarowało ponad $95 \%$ badanych). Wyniki analiz świadczą też o stosunkowo wysokim deklarowanym patriotyzmie lokalnym. Chęć dalszego zamieszkiwania w swojej gminie zadeklarowało $85,2 \%$ kobiet oraz $87,7 \%$ mężczyzn. Około $70 \%$ badanych zadeklarowało chęć wspierania kultury lokalnej (69,8\% kobiet i 71,5\% mężczyzn), na rozwój której gotowi byli przeznaczyć własne środki finansowe (taką deklarację złożyło 73,5\% kobiet oraz 77,1\% mężczyzn). Jako członkowie lokalnej społeczności obywatelskiej uczestniczyli w wyborach samorządowych (87,7\% kobiet oraz $89 \%$ mężczyzn).

Nieco większą wrażliwością na potrzeby innych i gotowością do niesienia pomocy oraz relatywnie wyższym poziomem poczucia podmiotowości charakteryzowały się kobiety. Chętnych do bezinteresownej pomocy innym było 83,3\% kobiet i 78,6\% mężczyzn, a na dziesięciopunktowej skali mierzącej poczucie podmiotowości najwyższe punkty $(8,9,10)$ wskazało $58,6 \%$ kobiet oraz $56,8 \%$ mężczyzn, najniższe natomiast $(1,2,3) 3,8 \%$ kobiet oraz $2,5 \%$ mężczyzn.

Badani nie różnili się w zakresie podzielania opinii dotyczącej współpracy trójsektorowej w lokalnych grupach działania. Niemal identyczny odsetek kobiet $(89,7 \%)$ i mężczyzn $(89,2 \%)$ uznał ją za konieczną. Wydaje się, iż responden-

\section{Tabela 2}

Odsetek respondentów, którym można przypisać poszczególne wartości indeksu zaufania

\begin{tabular}{|l|c|c|c|c|c|c|c|}
\hline \multirow{2}{*}{ Płeć } & \multicolumn{7}{|c|}{ Wartości indeksu zaufania, N =506 } \\
\cline { 2 - 8 } & 0 & 1 & 2 & 3 & 4 & 5 & 6 \\
\hline Kobieta & $2,8 \%$ & $2,8 \%$ & $10 \%$ & $26,1 \%$ & $28,9 \%$ & $18,5 \%$ & $10,9 \%$ \\
\hline Mężczyzna & $2,7 \%$ & $4,4 \%$ & $8,8 \%$ & $20 \%$ & $28,8 \%$ & $26,4 \%$ & $8,8 \%$ \\
\hline
\end{tabular}

Źródło: Opracowanie własne.

\footnotetext{
${ }^{4} 0$ cechowało respondentów, którzy deklarowali brak zaufania w stosunku do osób znanych, lokalnych instytucji i organizacji oraz byli nieufni w stosunku do osób obcych spotykanych w różnych sytuacjach życiowych, a 6 tych badanych, którzy w stosunku do nich cechowali się wysokim poziomem zaufania.
} 
tów, cechował wysoki poziom internalizacji wartości, jaką jest partnerstwo. $\mathrm{Na}$ pytanie o to, czyje interesy (ich zdaniem) reprezentuje większość członków lokalnych grup działania $81,7 \%$ kobiet oraz $85,5 \%$ mężczyzn wskazało, iż mieszkańców partnerstwa, $13,5 \%$ kobiet oraz 11,3\% mężczyzn było zdania, iż są to interesy sektora, który reprezentuja, zaledwie 4,8\% respondentek i 3,1\% respondentów wskazało, iż są to interesy osobiste. Odpowiedzi nie różniły się znacząco, gdy zadano im pytanie o to, czyje interesy reprezentują osobiście uczestnicząc w tych organizacjach. Około $86 \%$ kobiet i $90 \%$ mężczyzn uznało, że są to interesy mieszkańców partnerstwa, $11,1 \%$ respondentek i 7,8\% respondentów, iż są to interesy reprezentowanego sektora, 3\% kobiet i 2,6\% mężczyzn, że są to interesy osobiste. Można zatem wnioskować, że zdecydowana większość kobiet, ale również mężczyzn, należących do LGD deklaruje, iż w swoich działaniach reprezentują społeczność lokalną (mieszkańców partnerstwa), niezależnie od tego, z którego sektora są ,delegowani” do pracy w tej strukturze.

Indeks norm i wartości (skonstruowany analogicznie do indeksu zaufania), w skład którego weszły trzy zmienne syntetyczne - patriotyzm lokalny, normy i wartości społeczne oraz społecznikostwo badanych - przybrał wartości od 2 do 6. Wartości najwyższe w podgrupach płci osiagnęło $61 \%$ kobiet oraz 59,6\% mężczyzn (tab. 3).

Trzeci z komponentów kapitału społecznego kobiet zrzeszonych w lokalnych grupach działania scharakteryzowano za pomocą trzech zmiennych. Pierwszą było zaangażowanie respondentek w sieci współpracy na rzecz społeczności lokalnej wyrażające się w podejmowaniu prac na rzecz mieszkańców gminy, drugą ich uczestnictwo w pracach LGD, trzecią poczucie wpływu na funkcjonowanie partnerstwa.

Formy lokalnej aktywności różniły nieco kobiety i mężczyzn. Przed przystąpieniem do lokalnych grup działania prace na rzecz mieszkańców gminy wykonywało $65,1 \%$ kobiet oraz $81,7 \%$ mężczyzn. Respondentki znacznie rzadziej niż respondenci sprawowały funkcje publiczne (radnej, wójta/burmistrza, sołtysa), sponsorowały różne inicjatywy na rzecz mieszkańców gminy oraz były inicjatorkami protestów. Częściej niż mężczyźni pracowały natomiast w instytucjach

\section{Tabela 3}

Odsetek respondentów, którym można przypisać poszczególne wartości indeksu norm i wartości

\begin{tabular}{|l|c|c|c|c|c|}
\hline \multirow{2}{*}{$\begin{array}{l}\text { Płeć } \\
\text { respondenta }\end{array}$} & \multicolumn{5}{|c|}{ Wartości indeksu komponentu norm i wartości, N = 506 } \\
\cline { 2 - 6 } & 2 & 3 & 4 & 5 & 6 \\
\hline Kobieta & $0,5 \%$ & $10 \%$ & $28,4 \%$ & $34,1 \%$ & $26,9 \%$ \\
\hline Mężczyzna & $1 \%$ & $9,2 \%$ & $30 \%$ & $38,4 \%$ & $21,2 \%$ \\
\hline
\end{tabular}

Źródło: Opracowanie własne. 
działających na rzecz gminy i w związku z tym (również po godzinach pracy) angażowały się w życie gminy i pomoc jej mieszkańcom ${ }^{5}$ (tab. 4).

Większość z badanych kobiet (54\%) zaangażowała się w prace lokalnych grup działania dopiero w okresie programowania 2007-2013. Mężczyźni częściej uczestniczyli w nich dłużej (61\% ich ogółu było zrzeszonych w tych organizacjach od początku realizacji Pilotażowego Programu LEADER+). Te z respondentek, które pamiętały podejście LEADER z czasów Pilotażowego Programu LEADER+, częściej niż mężczyźni wskazywały, iż wtedy ich aktywność w LGD była mniejsza od przeciętnej (11,2\% wskazań w stosunku do 7,7\%), rzadziej stwierdzały, iż ich aktywność była ponad przeciętną (26\% wskazań kobiet w stosunku do $32 \%$ mężczyzn). Prezentowane różnice nie wynikały z oceny poziomu trudności realizacji podejścia LEADER w tamtym okresie. Niemal identyczny odsetek badanych kobiet i mężczyzn (odpowiednio 52 i 54\%) przyznał, iż procedury realizacji Pilotażowego Programu LEADER+ były skomplikowane. W okresie programowania 2007-2013 samoocena aktywności kobiet w lokalnych grupach działania uległa poprawie. Prawie co czwarta (podobnie jak co czwarty respondent) oceniła ją jako ponadprzeciętną (tab. 5).

\section{Tabela 4}

Odsetki respondentów deklarujących różne formy aktywności społecznej przed przystąpieniem do LGD

\begin{tabular}{|l|c|c|}
\hline Forma aktywności & Kobieta [\%] & Mężczyzna [\%] \\
\hline Sprawowanie funkcji publicznych & 30 & 57,6 \\
\hline Praca w instytucji działającej na rzecz gminy & 37,3 & 33,2 \\
\hline Praca w organizacji pozarządowej & 49,3 & 53,4 \\
\hline Sponsorowanie inicjatyw na rzecz mieszkańców gminy & 16,7 & 27,1 \\
\hline Zaangażowanie w inicjatywy na rzecz mieszkańców & 55,3 & 50,4 \\
\hline Zgłoszenie przedsięwzięcia do lokalnych instytucji & 30 & 34,7 \\
\hline Inicjator/ka protestu & 0 & 5,7 \\
\hline
\end{tabular}

Źródło: Opracowanie własne.

Tabela 5

Odsetki respondentów deklarujących określony poziom aktywności w LGD w okresie 2007-2013.

\begin{tabular}{|l|c|c|c|}
\hline \multirow{2}{*}{ Płeć } & \multicolumn{3}{|c|}{ Poziom aktywności w LGD w okresie 2007-2013, N = 561 [\%] } \\
\cline { 2 - 4 } & poniżej przeciętnej & przeciętny & ponadprzeciętny \\
\hline Kobieta & 14 & 62,3 & 23,7 \\
\hline Mężczyzna & 10,8 & 64,3 & 24,9 \\
\hline
\end{tabular}

Źródło: Opracowanie własne. ${ }^{5}$ Odsetki wskazań nie sumują się do $100 \%$, ponieważ respondenci mogli wskazać kilka pozycji
z kafeterii. 
Analiza syntetycznej zmiennej - aktywność respondentów w lokalnych grupach działania w okresie 2007-2013 - pozwoliła zauważyć, iż kobiety częściej niż mężczyźni osiagały jej najniższą wartość (tab. 6).

Kobiety w minimalnie większym stopniu niż mężczyźni uczestniczyły w realizacji inicjatyw lokalnych grup działania, ale nieco częściej niż oni przyznawały, iż należą do lokalnych grup działania tylko formalnie. $Z$ różnych względów przystapiły do organizacji, ale nie biorą aktywnego udziału w ich pracach. Ich uczestnictwo w zebraniach ogranicza się często do podpisania listy obecności (tab. 7).

Osoby partycypujące w realizacji inicjatyw LGD miały świadomość szczególnego wpływu na rozwój partnerstwa. Kobiety nieuczestniczące w działaniach thumaczyły się brakiem czasu oraz stwierdzały, że inni członkowie lokalnych grup działania sprawdzają się lepiej od nich w aktywnych formach (różnica w deklaracjach kobiet i mężczyzn w tym zakresie była znacząca, wynosiła prawie 10 punktów procentowych ${ }^{6}$ ). Oceniając swój wpływ na funkcjonowanie LGD kobiety rzadziej niż mężczyźni określały go jako duży (23,5\% wskazań w stosunku do 30,6\%), a częściej uważały go za średni (71,1\% w stosunku do $65,1 \%)$ - tabela 8 .

Tabela 6

Poziom aktywności respondentów w LGD w podziale na płeć

\begin{tabular}{|l|c|c|c|}
\hline \multirow{2}{*}{ Płeć } & \multicolumn{3}{|c|}{ Poziom aktywności w LGD, N =552 } \\
\cline { 2 - 4 } & 0 & 1 & 2 \\
\hline Kobieta [\%] & 10,3 & 67,4 & 22,3 \\
\hline Mężczyzna [\%] & 5,6 & 72,1 & 22,3 \\
\hline
\end{tabular}

Źródło: Opracowanie własne.

Tabela 7

Odsetki respondentów deklarujących określoną formę aktywności w LGD w podziale na płeć

\begin{tabular}{|l|c|c|c|}
\hline \multirow{2}{*}{ Płeć } & \multicolumn{3}{|c|}{ Forma aktywności w LGD, N = 561 } \\
\cline { 2 - 4 } & $\begin{array}{c}\text { formalne członkostwo } \\
{[\%]}\end{array}$ & $\begin{array}{c}\text { zabieranie głosu } \\
\text { na zebraniach [\%] }\end{array}$ & $\begin{array}{c}\text { działania przy realizacji } \\
\text { inicjatyw LGD [\%] }\end{array}$ \\
\hline Kobieta & 17 & 27,7 & 55,3 \\
\hline Mężczyzna & 12,5 & 33,3 & 54,2 \\
\hline
\end{tabular}

Źródło: Opracowanie własne.

\footnotetext{
${ }^{6}$ Odsetki nie sumują się do $100 \%$, ponieważ respondenci mogli podać kilka powodów braku uczestnictwa w inicjatywach LGD.
} 
Tabela 8

Powody braku uczestnictwa badanych w inicjatywach LGD ze względu na płeć

\begin{tabular}{|l|c|c|}
\hline \multirow{2}{*}{ Powód braku uczestnictwa w inicjatywach LGD } & \multicolumn{2}{|c|}{ Odsetki wskazań [\%] } \\
\cline { 2 - 3 } & kobieta & mężczyzna \\
\hline Brak czasu & 40,7 & 38,2 \\
\hline Brak doświadczeń we współpracy w ramach LGD & 19,8 & 21,4 \\
\hline Brak informacji o realizacji inicjatyw LGD & 9,9 & 11,7 \\
\hline Poczucie, że to inni sprawdza się lepiej & 44 & 34,8 \\
\hline Przekonanie o nieskuteczności inicjatyw & 0 & 7,1 \\
\hline $\begin{array}{l}\text { Przekonanie o tym, że zawsze w tych inicjatywach działaja } \\
\text { te same osoby }\end{array}$ & 12,1 & 14,8 \\
\hline
\end{tabular}

Źródło: Opracowanie własne.

\section{Tabela 9}

Opinie respondentów na temat efektów funkcjonowania lokalnych grup działania w podziale na płeć

\begin{tabular}{|l|c|c|}
\hline \multirow{2}{*}{ Funkcjonowanie LGD sprzyjało: } & \multicolumn{2}{|c|}{ Odsetki wskazań [\%] } \\
\cline { 2 - 3 } & kobieta & mężczyzna \\
\hline $\begin{array}{l}\text { zaangażowaniu mieszkańców obszaru partnerstwa } \\
\text { w działalność na jego rzecz }\end{array}$ & 76,6 & 77,3 \\
\hline $\begin{array}{l}\text { zmniejszeniu poziomu bezrobocia wśród mieszkańców obszaru } \\
\text { partnerstwa }\end{array}$ & 25,4 & 32,2 \\
\hline rozwojowi kwalifikacji i umiejętności członków LGD & 73,2 & 79,7 \\
\hline rozwojowi działalności pozarolniczej na obszarze partnerstwa & 64,4 & 66,8 \\
\hline promocji gmin tworzących obszar partnerstwa & 87,5 & 88,6 \\
\hline integracji i współpracy członków LGD & 74,3 & 76,9 \\
\hline
\end{tabular}

Źródło: Opracowanie własne.

Tabela 10

Odsetek respondentów, którym można przypisać poszczególne wartości indeksu sieci

\begin{tabular}{|l|c|c|c|c|c|c|c|}
\hline \multirow{2}{*}{ Płeć respondenta } & \multicolumn{7}{|c|}{ Wartości indeksu sieci, $\mathrm{N}=423$} \\
\cline { 2 - 8 } & 0 & 1 & 2 & 3 & 4 & 5 & 6 \\
\hline Kobieta [\%] & 0,6 & 4,5 & 19,2 & 33,9 & 24,3 & 14,1 & 3,4 \\
\hline Mężczyzna [\%] & 0,4 & 2,4 & 8,5 & 32,5 & 33,7 & 17,5 & 4,9 \\
\hline
\end{tabular}

Źródło: Opracowanie własne. 
Jeśli chodzi o efekty funkcjonowania lokalnych grup działania, to badani mieli dosyć podobną opinię na ich temat. Ich zdaniem podejście LEADER zaowocowało głównie promocją obszaru partnerstwa, zaangażowaniem jego mieszkańców w działalność na jego rzecz oraz integracją i współpracą członków LGD (tak określone efekty mogły skutkować wzrostem ich kapitału społecznego). Oceniając oddziaływanie LGD na zmniejszenie poziomu bezrobocia wśród mieszkańców obszaru partnerstwa, respondentki były nieco bardziej sceptyczne niż respondenci (tab. 9).

Skonstruowany indeks sieci pokazuje różnice między deklaracjami obu płci. Najwyższe wartości na skali (5 i 6) nieco częściej osiaggali mężczyźni, najniższe (0 i 1 ) kobiety (tab. 10).

\section{Wnioski}

Analizowany materiał pokazuje różnice w poziomie kapitału ludzkiego i społecznego kobiet i mężczyzn należących do LGD. W porównaniu do mężczyzn częściej przystępowały do nich kobiety młodsze, nieco mniej wykształcone. Badane rzadziej niż mężczyźni zasiadały we władzach i częściej reprezentowały sektor społeczny. Rzadziej osiągały najwyższe wartości, przypisywane różnym cechom składającym się na komponenty kapitału społecznego, jak poziom zaufania i sieci powiązań. Co do komponentu norm i wartości, ich przewaga nad mężczyznami dotyczyła deklarowanej wrażliwości na potrzeby innych i gotowości do niesienia im pomocy oraz relatywnie wyższego poziomu poczucia podmiotowości. Warto zaznaczyć, że w ocenie efektów funkcjonowania lokalnych grup działania, nie zaznaczały się istotne różnice pomiędzy kobietami a mężczyznami. Respondenci uważali, że podejście LEADER zaowocowało głównie promocją obszaru partnerstwa, ale zwrócili też uwagę na aktywizującą rolę programu. Ich zdaniem, widoczne było zaangażowanie mieszkańców partnerstwa w działalność na rzecz realizacji ogólnie rozumianych potrzeb społecznych danego terenu, wzrósł poziom integracji członków LGD. Tak postrzegane efekty mogły skutkować wzrostem kapitału społecznego na obszarze partnerstw. Ważne jest zwrócenie przez respondentów uwagi na możliwość rozwoju działalności pozarolniczej, zgodnie z ideą wielofunkcyjnego rozwoju obszarów wiejskich, która, z założenia, powinna przyświecać inicjatywom LEADER-a. Nieco bardziej sceptycznie respondenci odnosili się, zwłaszcza kobiety, do możliwości wpływu działalności LGD na zmniejszenie poziomu bezrobocia wśród mieszkańców partnerstwa. 


\section{Literatura}

BOGUSZEWSKI R., 2012: Aktywność społeczna w organizacjach obywatelskich, CBOS, komunikat 18/2012.

BUKRABA-RYLSKA I. (red.), 2011: Między interwencja a interakcja. Lokalne grupy dziatania w spolecznościach wiejskich, Wydawnictwo Naukowe SCHOLAR, Warszawa.

FURMANKIEWICZ M., KRÓLIKOWSKA K., 2010: Partnerstwa terytorialne na obszarach wiejskich $w$ Polsce $w$ latach 1994-2006, Wydawnictwo Uniwersytetu Przyrodniczego we Wrocławiu, Wrocław.

FURMANKIEWICZ M. 2013: Wspótrzqdzenie czy ukryta dominacja sektora publicznego? Koncepcja governance w praktyce lokalnych grup działania LEADER, Studia Regionalne i Lokalne 1(51), 71-89

HALAMSKA M., MICHALSKA S., ŚPIEWAK R., 2010: LEADER w Polsce. Drogi implementacji programu, Wieś i Rolnictwo 4(149), 104-119.

HALAMSKA M., 2011: Sceny rozwoju lokalnego w Polsce: dekoracje i aktorzy, Wieś i Rolnictwo 4(153), s. 103-122.

HERBST J. 2008: Wieś obywatelska, [w:] J. Wilkin, I. Nurzyńska (red.), Polska wieś 2008. Raport o stanie wsi, Fundacja na Rzecz Rozwoju Polskiego Rolnictwa, Warszawa, s. $159-180$.

HIPSZ N., 2012: Potencjat społecznikowski i zaangażowanie Polaków w wolontariat, CBOS, komunikat 23/2012.

KAMIŃSKI R. 2008: Aktywność społeczności wiejskich, IRWiR PAN, Warszawa.

KINOWSKA Z., 2013: Kondycja społeczeństwa obywatelskiego w Polsce, Infos 22(136), s. $1-4$.

KNIEĆ W., 2010: Partnerstwa lokalne w Polsce - kondycja, struktura, wyzwania, Raport badawczy, Fundacja Partnerstwo dla Środowiska, Kraków, Torun.

KNIEĆ W., 2007: Władza w LGD, Kwartalnik LEADER+ 4, s. 18-19.

MICHALSKA S., 2013: Tradycyjne i nowe role kobiet wiejskich, Wieś i Rolnictwo 2(159), s. $124-140$.

Program Rozwoju Obszarów Wiejskich na Lata 2007-2013, 2007: Ministerstwo Rolnictwa i Rozwoju Wsi, Warszawa.

PRZEWŁOCKA J., ADAMIAK P., HERBST J., 2013: Podstawowe fakty o organizacjach pozarzqdowych, Stowarzyszenie Klon/Jawor, Warszawa.

PSYK-PIOTROWSKA E., ZAJDA K., KRETEK-KAMIŃSKA A., WALCZAK-DURAJ D., 2013: Struktura i uwarunkowania kapitału społecznego lokalnych grup działania, Wydawnictwo UŁ, Łódź.

PUTNAM R., 1995: Demokracja $w$ działaniu. Tradycje obywatelskie we wspótczesnych Włoszech, Społeczny Instytut Wydawniczy ZNAK, Fundacja im. S. Batorego, Kraków-Warszawa

WALCZAK-DURAJ D. 2008: Podstawowe sfery potencjalnego uczestnictwa kobiet wiejskich $w$ życiu społeczno-politycznym, [w:] J. Krzyszkowski (red.), Diagnoza sytuacji społeczno-zawodowej kobiet wiejskich w Polsce, Ministerstwo Pracy i Polityki Społecznej, Warszawa, s. 125-164

ZAJDA K., 2011: Nowe formy kapitału społecznego wsi, Wydawnictwo UŁ, Łódź. 


\title{
The impact of the LEADER approach on the social capital of rural women - members of the local action groups
}

\begin{abstract}
In the article there is an analysis of the impact of the LEADER approach on the social capital of rural women involved in the local action groups. The aim of the article is to characterize the features of this capital taking into consideration the capital belonging to men involved in these organizations. The question is whether the role of local action groups as far as the social capital is concerned equally applies to women and men associated in these structures. On the basis of the research carried out in 2011-2013 (on a sample of 238 women and 327 men) within the framework of the project entitled: "Structure and determinants of social capital of local action groups" (National Science Centre grant) women social capital analysis was made (with its definition by R. Putnam). In the social survey distributed surveys technique was used. The result of the analysis is a statement that women social capital differs from men social capital mainly in the area of trust component and network component.
\end{abstract}

